\title{
Microcefalia y virus Zika, un reto en Bolivia y América Latina
}

\author{
Microcephaly and Zika virus, a challenge in Bolivia and Latin America
}

\section{Sr. Editor:}

El motivo de esta carta, es el número creciente de infecciones por el virus Zika (ZIKV) reportados por la OPS/OMS en Bolivia como problemática compartida en América y las subsiguientes complicaciones con las que está relacionada.

La OMS reportó desde la primera semana epidemiológica de 2017, una tendencia creciente de casos sospechosos y confirmados como resultado del aumento registrado de casos en Argentina, Bolivia, Brasil, Ecuador y Perú (1).

El Ministerio de Salud de Brasil en octubre de 2015, informó sobre el incremento de casos de microcefalia en el estado de Pernambuco, en promedio, en este estado se registraban solamente 10 casos de microcefalia por año, no obstante, en fecha 11 de noviembre se detectaron 141 casos de microcefalia en 44 de los 185 municipios de este estado (2).

Asimismo, el 30 de enero del 2016 en Brasil se registraron 4783 casos de microcefalia y/o malformación congénita a nivel neurológico, sugerentes de infección congénita, de las cuales 76 correspondían a defunciones; de esta manera, se registró un promedio de 163 casos de microcefalia por año en el periodo de 2001 al 2014 (3).

En el caso particular de Bolivia, el Ministerio de Salud confirmó el tres casos de microcefalia en recién nacidos provenientes del departamento de Santa Cruz. En la actualización epidemiológica del 6 de octubre de 2016 de la OMS, Granada era considerado como el último país en notificar un caso confirmado de síndrome congénito asociado con la infección por el ZIKV. Sin embargo, en la actualidad, Bolivia es el último país que notificó oficialmente tres casos confirmados positivos de síndrome congénito asociado con la infección por ZIKV (4).

Así mismo, Mlakar J et al (5), presentaron el caso de una mujer europea previamente sana de 25 años de edad, gestante, con antecedentes clínicos sugerentes de infección viral fetal y ecografía a las 32 semanas que confirmaba el retraso del crecimiento intrauterino, una placenta con numerosas calcificaciones, perímetro cefálico inferior al segundo percentil para la gestación, ventriculomegalia, un diámetro transcerebelar debajo del segundo percentil; de esta manera, considerando este suceso, son más los casos que confirman la relación de ZIKV y microcefalia, por lo que es conveniente el seguimiento y control de regiones endémicas o con brotes con el fin de registrar y compartir los datos obtenidos con los demás países comprometidos.

Bajo estas consideraciones, es fundamental el trabajo conjunto, coordinado entre países, para lograr reducir la incidencia en los países afectados y consecuentemente evitar la expansión a otros. Hoy Bolivia se encuentra en alerta por el número creciente de casos de ZIKV (6), considerándose un reto en los países comprometidos de América Latina, es clave que los académicos y científicos concentren sus esfuerzos en la profundización del estudio de esta patología.

Finalmente, estoy convencido que promover e incentivar el estudio de esta enfermedad en los centros de enseñanza de Medicina en pregrado, es clave para valorar y dar importancia a este tema, formando sujetos activos, apasionados por la temática, creativos y con un compromiso tenaz, imparciales a la hora de resolver problemas de esta índole.

Aarón Eduardo Carvajal-Tapia 1,a 


\section{Correspondencia}

Aarón Eduardo Carvajal Tapia

Zona Jaihuayco, Av. Killman Cochabamba, Bolivia

Correo: aecarvajal3@gmail.com

Celular: 59165194597

\section{REFERENCIAS BIBLIOGRÁFICAS}

1. Organización Panamericana de la Salud, Organización Mundial de la Salud. Zika Actualización Epidemiológica Regional de la OPS (Américas) 12 de enero de 2017 [Internet]. OPS/OMS; 2017 [Consultado 01 de Julio de 2017]. Disponible en: http://www.paho.org/hq/index.php?option=com content\&id=11599\&Itemid=41691\&lang $=$ es

2. Organización Panamericana de la Salud, Organización Mundial de la Salud. Alerta Epidemiológica Incremento de microcefalia en el nordeste de Brasil. [Internet] OPS/OMS; 2015. [Consultado 02 de Junio de 2017]. Disponible en: http://www.paho.org/hq/ index.php?option $=$ com_docman\&task $=$ doc_view \&It emid $=270 \&$ gid $=32286 \&$ lang $=$ es
3. Organización Panamericana de la Salud, Organización Mundial de la Salud. Aumento de microcefalia congénita y otros síntomas del sistema nervioso central [Internet]. OPS/OMS; 2016. [Consultado 12 de febrero de 2017] Disponible en: http://www.paho. org/hq/index.php?option=com_content\&view $=$ articl e\&id $=11675 \&$ Itemid $=41711$ \&lang $=$ es

4. Ministerio de Salud de Bolivia. Santa Cruz: Ministerio de salud confirma tres casos de zika en recién nacidos. La Paz, Bolivia. [Internet]. Bolivia Minsalud; 2016. [Consultado el 10 de febrero del 2017]. Disponible en: https://www.minsalud.gob. bo/1774-santa-cruz-ministerio-de-salud-confirmatres-casos-de-zika-en-recien-nacidos

5. Mlakar J, Korva M, Tul N, Petrovec M, Zupanc TA. Zika Virus Associated with Microcephaly. N Engl J Med. 2016; 10:951-8. DOI: 10.1056/ NEJMoa1600651

6. Carvajal-Tapia AE. Virus Zika, una enfermedad emergente en Bolivia. Colomb J Med Students. 2017; 1(1):16-22. Disponible en: https://www.ascemcol. org/publicaciones/

Recibido: 21/08/2017 